Revue de droit comparé du travail et de la sécurité sociale

4 | 2017

English Electronic Edition

\title{
Recent Changes in Czech Labour Law and Social Security Law (First and Second Semester 2016/2017). Focused on Home Birth
}

Martin Štefko

\section{OpenEdition}

Journals

Electronic version

URL: https://journals.openedition.org/rdctss/2524

DOI: $10.4000 /$ rdctss. 2524

ISSN: 2262-9815

Publisher

Centre de droit comparé du travail et de la sécurité sociale

Printed version

Date of publication: 1 December 2017

Number of pages: $248-249$

ISSN: $2117-4350$

Electronic reference

Martin Štefko, "Recent Changes in Czech Labour Law and Social Security Law (First and Second Semester 2016/2017). Focused on Home Birth", Revue de droit comparé du travail et de la sécurité sociale [Online], 4 | 2017, Online since 01 November 2021, connection on 04 December 2021. URL: http://journals.openedition.org/rdctss/2524 ; DOI: https://doi.org/10.4000/rdctss.2524

\section{(C) $\Theta \Theta \Theta$}

Revue de droit comparé du travail et de la sécurité sociale est mise à disposition selon les termes de la Licence Creative Commons Attribution - Pas d'Utilisation Commerciale - Pas de Modification 4.0 International. 


\title{
MARTIN ŠTEFKO
}

\author{
Charles University in PragVe ${ }^{1}$
}

\section{Recent Changes in Czech Labour Law and Social Security LaW \\ (FIRST AND SECOND SEMESTER 2016/2017) FOCUSED ON HOME BIRTH²}

The Czech legislator has set forth so onerous requirements for home birth as to effectively negate the possibility of having home birth. Although there are no laws forcing a woman to go to hospital to give birth - so every woman has the right to insist that she is staying at home to have her baby, she is as a result of said State policy not able to reach any home birth service. This serious reduction in the rights of users of health care apparently occurred without much debate and with little comment from the government. It has been suggested that, if this change in the law took place without sufficient debate, it will be soon the subject of a judicial review, what happened on both national and international level.

The European Court of Human Rights appraised Czech policy in Dubská and Krejzová v. the Czech Republic (applications Nos. 28859/11 and 28473/12). Although the ECHR considers home births as a part of private life, Article 8 of the Convention for the Protection of Human Rights and Fundamental Freedoms does not constitute a right to give birth at home as such. The court examined three main factors in order to evaluate the measures adopted by the national authorities to deal with those risks: whether they gave due weight to the competing interests and whether they carefully considered the possible alternatives and assessed the proportionality of their policy in respect of home births.

On national level after Dubská and Krejzová in another case, the Supreme court of the Czech Republic upheld, in its judgement (dated 15 June 2016, file number 30 Cdo 3598/2014), the described State policy as well. The plaintiff brought a maladministration claim against the state as it did not ensure care during home births, and had not enacted the necessary legislation. As a result, the plaintiff had to give birth at home without qualified care. The courts of the first and second instance dismissed the claim.

The plaintiff appealed on the grounds that courts review the plaintiff objected to the decisions stating that the courts omitted to consider Art. 8 of the Convention on the Protection of Human Rights and Fundamental Freedoms and Art. 10 para. 2 of the Charter of Rights and Freedoms. She also contended that the Czech Republic had paid lip service to the Parliament and Council Directive No. 2005/36/EC and the Council Directive No. 80/155/ EEC, which deals with the activities of midwives at home births. She further contended that the Czech Republic acted in breach of its obligations under EU-law and that constituted maladministration.

The article has been written and published thanks to the financial support of the grant project "Soukromé právo a výzvy dneška " [Civil Law and Challenges of the Day], identity code Q03.

2 The author of this report does not wish to either promote or condemn planned unassisted birth, the aim of this section is simply inform about Czech regulations, practice and test cases. 
The Supreme Court continued the settled practice and stated that as a matter of principle legislative activity may not have been considered as maladministration, which applied also to the government's statutes. The Supreme Court stated that there wasn't a rule in the Czech legislation that would have ordered the health authorities to provide a home birth service, and the obligation may not have been deduced from Art. 8 of the Convention as well. The court further came to the conclusion that no article of the Council Directive No. 80/155/EEC imposed a duty to ensure medical care for pregnant women during home births by midwives, and the Czech legal regulation enabling midwives to help women during physiological births in health care institutions did not contradict said directive. The EU-law was adopted to eliminate discrimination of midwives coming from individual member states of the European Union on the basis of nationality, and to ensure their free movement and freedom of settlement, and not to determine conditions for providing medical services.

Given the evidence that home birth is both safe for normal births, and cheaper than hospital birth, it should be hard for a Czech health authority to argue that providing a home birth service was not in the woman's best interest, or that it was not an effective use of resources. Even so, the State policy is geared against home birth for one main reason: a paternalistic vision of zero-risk births that can be provided only in full equipped and manned hospitals. The opposing mothers' movement campaigns for home birth not because of low professionality or costs of health case but because Czech public hospitals are still unable to provide nice and friendly atmosphere for mothers-to-be. ${ }^{3}$

So, it must be considered as a matter of fact that if a woman sought a judicial review of a health authority's refusal to provide a home birth service, she might be not in a good position because there is no legal right for the woman to insist upon a home confinement. Czech legislator assumes that hospital birth is always better even if the woman can show that it is not in her best interests and that the resource implications are in the national health care insurance scheme's favour.

3 Cf. Koldinska, K.: The Policy on Gender Equality in the Czech Republic available at http://www. europarl.europa.eu/RegData/etudes/IDAN/2015/510009/IPOL IDA(2015)510009 EN.pdf or Černá, A.: Home Births as Hazzard or the Only One Alternative, available at http://www.info.cz/ cesko/hazard-nebo-jedina-alternativa-domaci-porody-rozdeluji-ceskou-verejnost-5902.html 